\title{
Effect of storage temperature on crystal formation rate and growth rate of calcium lactate crystals on smoked Cheddar cheeses
}

\author{
P. Rajbhandari, J. Patel, E. Valentine, and P. S. Kindstedt ${ }^{1}$ \\ Department of Nutrition and Food Sciences, University of Vermont, Burlington 05405-0086
}

\begin{abstract}
Previous studies have shown that storage temperature influences the formation of calcium lactate crystals on vacuum-packaged Cheddar cheese surfaces. However, the mechanisms by which crystallization is modulated by storage temperature are not completely understood. The objectives of this study were to evaluate the effect of storage temperature on smoked Cheddar cheese surfaces for (1) the number of discrete visible crystals formed per unit of cheese surface area; (2) growth rate and shape of discrete crystals (as measured by area and circularity); (3) percentage of total cheese surface area occupied by crystals. Three vacuum-packaged, random weight $(\sim 300 \mathrm{~g})$ retail samples of naturally smoked Cheddar cheese, produced from the same vat of cheese, were obtained from a retail source. The samples were cut parallel to the longitudinal axis at a depth of $10 \mathrm{~mm}$ from the 2 surfaces to give six 10-mm-thick slabs, 4 of which were randomly assigned to 4 different storage temperature treatments: $1,5,10^{\circ} \mathrm{C}$, and weekly cycling between 1 and $10^{\circ} \mathrm{C}$. Samples were stored for 30 wk. Following the onset of visible surface crystals, digital photographs of surfaces were taken every other week and evaluated by image analysis for number of discrete crystal regions and total surface area occupied by crystals. Specific discrete crystals were chosen and evaluated biweekly for radius, area, and circularity. The entire experiment was conducted in triplicate. The effects of cheese surface, storage temperature, and storage time on crystal number and total crystal area were evaluated by ANOVA, according to a repeatedmeasures design. The number of discrete crystal regions increased significantly during storage but at different rates for different temperature treatments. Total crystal area also increased significantly during storage, at rates that varied with temperature treatment. Storage temperature did not appear to have a major effect on the growth rates and shapes of the individual crystals that were chosen for analysis. The data indicated that
\end{abstract}

Received July 16, 2012.

Accepted February 17, 2013.

${ }^{1}$ Corresponding author: paul.kindstedt@uvm.edu the effect of storage temperature was complex, likely involving solubility changes, the formation of $\mathrm{D}(-)$ and $\mathrm{L}(+)$ lactic acid, and the occurrence of syneresis, which in turn affected the number of crystal formation sites and total crystal area on the cheese surface.

Key words: Cheddar cheese, calcium lactate, crystal

\section{INTRODUCTION}

The occurrence of white deposits on the surface and within the body of Cheddar cheese has been studied since the 1930s. Using x-ray diffraction methodology, several researchers have identified the white deposits in Cheddar cheese as crystals of calcium lactate (Tuckey et al., 1938; Conochie et al., 1960; Pearce et al., 1973; Chou et al., 2003), tyrosine (Conochie et al., 1960), or both calcium lactate and tyrosine in the same cheese (Shock et al., 1948; Harper et al., 1953). Washam et al. (1985) concluded that crystals on the surface of retailpackaged Cheddar cheese were calcium lactate, based on analyses using scanning electron microscopy coupled with energy dispersive x-ray microanalysis. Chemical analyses have also been used to determine the composition of white crystalline deposits recovered from the surface (Farrer and Hollberg, 1960; Rajbhandari and Kindstedt, 2005a) or interior (McDowall and McDowell, 1939) of Cheddar cheese. These studies reported that the crystals contained from 60 to $72 \%$ calcium lactate pentahydrate, 10 to $20 \%$ free moisture, and up to $16 \%$ free lactate.

High levels of calcium and lactate ions in the serum phase may result in calcium lactate crystal formation on the surface of vacuum-packed Cheddar cheeses (Dybing et al., 1988; Swearingen et al., 2004). Cheddar cheeses that are smoked naturally are particularly vulnerable to surface crystallization because dehydration combined with the absorption of acidic volatiles at the surface during smoking result in elevated levels of calcium and lactate ions in the serum phase at the cheese surface (Rajbhandari and Kindstedt, 2005a; Rajbhandari et al., 2009). Surface crystals of calcium lactate have long been known as quality defects that affect sales and marketability of the cheeses. Although they do not pose a health risk, they are considered 
unsightly and inedible and thus create financial burden for the industry (Washam et al., 1985; Swearingen et al., 2004).

For crystallization to occur, the reacting constituents must exceed their solubility, nucleate, form micro crystals, and grow into macro crystals (Hartel, 2001). The solubility of calcium lactate in aqueous solution is temperature dependent and increases with increasing temperature (Pearce et al., 1973; Kubantseva et al., 2004). Furthermore, calcium lactate may occur in either isomeric form, $\mathrm{L}(+)$ or $\mathrm{D}(-)$, or as a mixture of the 2 isomers. Cao et al. (2001) reported that the solubility of $\mathrm{L}(+)$ calcium lactate in aqueous solution is higher than that of a DL mixture at 5 and $10^{\circ} \mathrm{C}$, which represent temperatures at which cheeses are normally aged and stored. Although temperature clearly influences the solubility of calcium lactate in aqueous solution, the effect of temperature on calcium lactate crystallization in cheese may involve more than solubility alone because cheese is a complex matrix consisting of water-soluble and water-insoluble constituents, enzymes, and microorganisms. Thus, temperature may have multifaceted, and potentially confounding, effects on the chemical and microbial environment of cheese. For example, high storage temperature has been shown to encourage the growth of nonstarter lactic acid bacteria (NSLAB), which racemize $\mathrm{L}(+)$ to $\mathrm{D}(-)$ lactate, thereby triggering crystal growth on the surface of Cheddar cheeses (Johnson et al., 1990b). Furthermore, cheeses that were subjected to alternating high and low storage temperatures and that were packaged loosely displayed pronounced crystal development (Johnson et al., 1990a). Similar results regarding temperature were observed by Chou et al. (2003) for cheeses that were inoculated with NSLAB and then subjected to higher temperature followed by lower temperature storage. Swearingen et al. (2004) concluded that serum separation on the surfaces of cheeses stored at $7^{\circ} \mathrm{C}$ or below was also associated with crystal defect. Dybing et al. (1988) showed that cheeses packaged with carbon dioxide gas flushing and then stored at different temperatures showed varying results. Cheeses at 2 and $12^{\circ} \mathrm{C}$ had fewer crystals than cheeses stored at either 4 or $6^{\circ} \mathrm{C}$, with maximum crystal coverage occurring at $6^{\circ} \mathrm{C}$. Thus, the effect of storage temperature on calcium lactate crystal formation appears to be complex and multifaceted.

Little is known about how temperature affects crystallization from a mechanistic point of view; that is, whether temperature affects the number of nucleation sites at which crystals may form and grow to a visible threshold, or the rate at which crystals grow post-nucleation, or both the number of nucleation sites and post-nucleation growth rate. One reason for this gap in understanding has been the limited abil- ity to quantitatively measure crystal characteristics on the cheese surface. Recently, we developed an image analysis method that enables changes in crystal number, area, and growth rate to be determined over time (Rajbhandari and Kindstedt, 2005b, 2008). The objective of the present study was to apply image analysis methodologies to investigate the mechanism by which storage temperature influences the formation of calcium lactate crystals on the surface of smoked Cheddar cheese. Smoked Cheddar was chosen for the study because of its predisposition to surface crystal formation and its suitability for image analysis because of the sharp contrast between the dark cheese surface and white crystals.

\section{MATERIALS AND METHODS}

The Cheddar cheese samples used in this study were commercially manufactured and obtained from retail sources. These cheeses were produced by a milled curd procedure using an automated production line that included enclosed vats $(22,727-\mathrm{kg}$ capacity) for coagulating the milk and cooking the curd; an enclosed conveyor series for continuous dewheying, cheddaring, and milling; enclosed mechanical metering of dry salt and automated stirring of salted curd; and block-forming towers that produced 19.1-kg blocks. The blocks were vacuum-packaged and aged for 3 mo before being cut into retail-sized chunks (approximately $47 \times 60 \times 100$ $\mathrm{mm})$ for smoking. Cheeses were smoked at a commercial smokehouse where they were exposed to natural vaporous smoke at $20^{\circ} \mathrm{C}$ for approximately $6 \mathrm{~h}$. After smoking, the samples were vacuum-packaged and sent to retail stores.

For each experimental trial, 3 cheese samples produced at the same plant on the same day from the same vat were purchased from a local supermarket. The entire experiment was conducted in triplicate using 3 different sets of 3 cheese samples produced at the same plant but on different days (August 26, September 2, and December 8, 2005). The cheese samples ranged from approximately 8 to $10 \mathrm{mo}$ of age from the date of manufacture. Upon receipt of samples, the packaging material was removed and samples were sectioned along the longitudinal axis at a depth of $10 \mathrm{~mm}$ from the 2 largest surfaces $(100 \mathrm{~mm})$ opposite one another to give six 10-mm-thick slabs. Each slab contained one surface that was exposed to the atmosphere during smoking (smoked surface) and an opposite interior cut surface that was not exposed during smoking (Figure $1)$. Four of these slab sections were randomly chosen, immediately vacuum-packaged in 3.2-mil polyethylenepolyamide laminated vacuum pouches (Industrial $\mathrm{Pa}-$ per and Packaging Inc., Middleton, WI) at $1 \mathrm{kPa}$ (very 


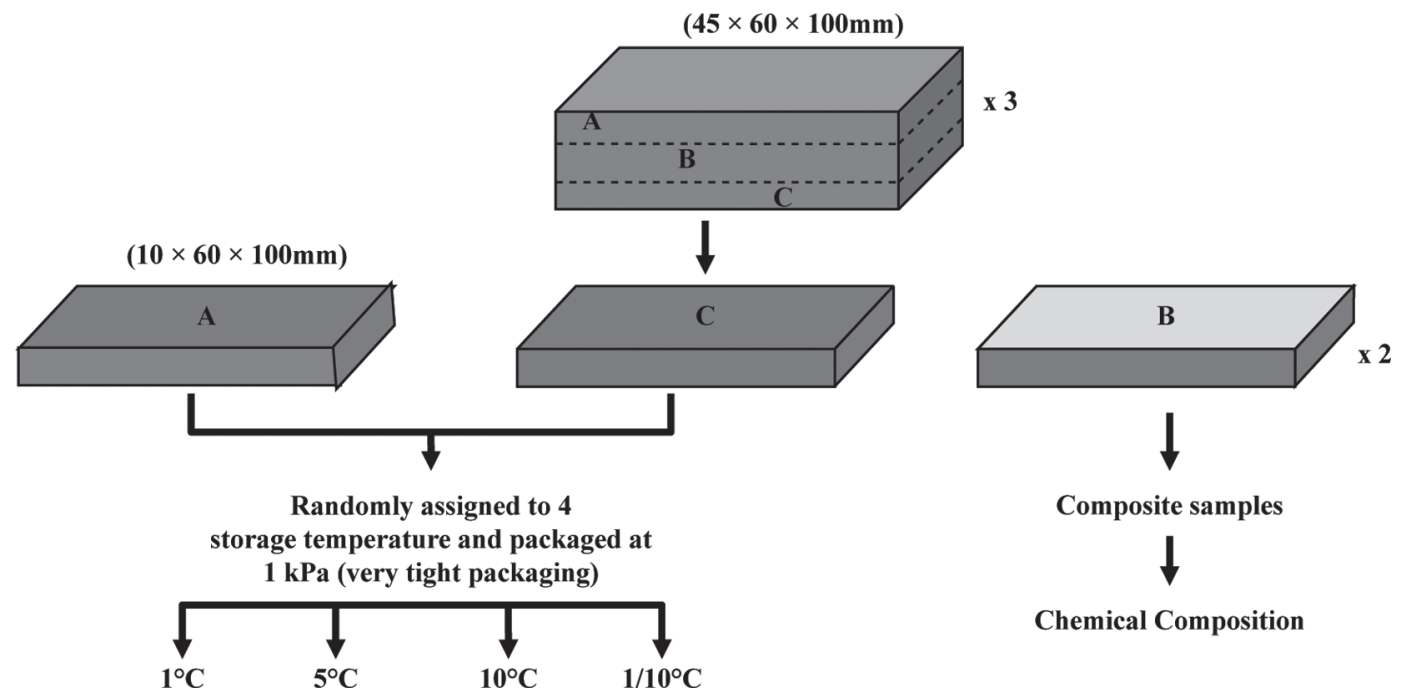

Figure 1. Schematic representation of sectioning plan used to prepare cheese samples for analyses. Retail-sized cheese block: (A) 10 mm below the surface, (B) $10 \mathrm{~mm}$ interior section, and (C) $10 \mathrm{~mm}$ below the opposite surface.

tight packaging) using a Multivac packaging machine (model A300/16 machine, Multivac Sepp Haggenmuller KG, Wolfertschwenden, Germany), and randomly assigned to storage temperatures of 1,5 , or $10^{\circ} \mathrm{C}$, or weekly cycling between 1 and $10^{\circ} \mathrm{C}$ (hereafter, $1 / 10^{\circ} \mathrm{C}$ ). The interior portions remaining after removal of the surface slabs from each of the 3 cheese samples (Figure 1) were vacuum-packaged and stored at $1^{\circ} \mathrm{C}$ until they were used for chemical analysis.

Digital photographs of the smoked surfaces of slab sections were taken biweekly for 30 wk using a still digital camera (model no. E5200, 5.1 megapixels, Nikon Corp., Tokyo, Japan). Images of the samples were analyzed for (a) percentage of total cheese surface area occupied by crystals, and (b) number of discrete crystal regions (DCR) expressed per square centimeter of cheese surface area. For 2 of the 3 trials, 2 pinpoint DCR on the surface of each treatment cheeses were randomly chosen and analyzed biweekly for growth rate and shape (measured by area and circularity of the discrete crystal regions) using the image analysis method (Metamorph offline, version 7.1.2.0, Molecular Devices LLC, Sunnyvale, CA) described by Rajbhandari and Kindstedt, 2005b, 2008). Only the smoked surfaces were analyzed for image analysis.

Compositional analyses were conducted in duplicate at the end of the 30-wk study using the interior portions (Figure 1) that were stored at $1^{\circ} \mathrm{C}$. Moisture content was determined by drying in a forced-draft oven (model 130DM, Thermo Electron, Winchester, VA) at $100^{\circ} \mathrm{C}$ for $24 \mathrm{~h}$. Cheese $\mathrm{pH}$ was measured using a Beckman $50 \mathrm{pH} / \mathrm{ISE}$ Meter (Beckman Instruments Inc., Fullerton, CA) by direct immersion of a Ross combination spear-tip pH electrode (Orion Research Inc.,
Beverly, MA) into a finely ground sample at ambient temperature. Amounts of $\mathrm{L}(+), \mathrm{D}(-)$, and total lactic acid were determined by a colorimetric method (test kit no. 11112821035, Boehringer Mannheim/R-Biopharm AG, Darmstadt, Germany). In addition, $\mathrm{L}(+)$ and $\mathrm{D}(-)$ lactate contents of experimental cheese samples at each temperature treatment for 2 of the 3 trials were measured at the end of the storage period ( $30 \mathrm{wk})$. Fat content was determined by Babcock method (Marshall, 1993), and salt content was determined by using a chloride analyzer (M926, Nelson and Jameson, Marshfield, WI). The amount of free serum present on the surface of the slab sections in each temperature treatment following the completion of the study ( $45 \mathrm{wk}$ ) for 2 of the 3 trials was evaluated by removing the packaging film and gently blotting the film and cheese surfaces with a preweighed tissue $(11 \times 21 \mathrm{~cm})$ and reweighing the tissue after blotting.

The smoked surface data obtained from image analysis were analyzed by ANOVA according to a repeatedmeasures design with 1 within-subject variable and 1 between-subject variable (SPSS version 15.0, SPSS Inc., Chicago, IL). The within-subject variable was storage time (0 to $30 \mathrm{wk}$ ) and the between-subject variable was temperature treatment $\left(1,5,10\right.$, and $\left.1 / 10^{\circ} \mathrm{C}\right)$. Significance was determined at the 0.05 level of probability. Average values of 2 DCR areas of 4 temperature treatments were obtained and slopes of regression lines were statistically compared using SAS software (SAS Institute Inc., Cary, NC).

\section{RESULTS AND DISCUSSION}

The chemical composition of cheese samples in the present study was within the range previously reported 
for commercial smoked Cheddar cheese produced at the same manufacturing plant (Rajbhandari and Kindstedt, 2005a; Rajbhandari et al., 2009). The moisture content, $\mathrm{pH}$, salt, fat, protein, and total lactic acid were $34.36 \pm 0.54 \%, 5.15 \pm 0.03,1.76 \pm 0.0 \%, 35.5 \pm 0.71 \%$, $25.87 \pm 0.89 \%$, and $1.28 \pm 0.26 \%$, respectively. Natural smoked cheeses were selected for this study because our previous research showed that smoked cheeses tend to be more susceptible to crystal formation because of surface dehydration and interaction with smoke constituents (Rajbhandari et al., 2009). Thus, the use of smoked cheeses served as an advantage to conduct accelerated studies on the effect of storage temperature on crystallization.

The total area occupied by crystals on the smoked surfaces of slab sections stored at 4 temperature treatments is shown in Figure 2. The total area increased linearly for cheeses stored at $1^{\circ} \mathrm{C}$ and $5^{\circ} \mathrm{C}$ over a period of $30 \mathrm{wk}$, whereas the total area increased in a nonlinear manner, best described by a quadratic relationship $\left(\mathrm{R}^{2}\right.$ $=0.92-0.99$ ), for cheeses stored at $10^{\circ} \mathrm{C}$ and $1 / 10^{\circ} \mathrm{C}$. The total area was significantly affected by storage time and by the interaction of storage time by storage temperature (Table 1). We observed an increase in crystal area as time progressed, and the total area increased at different rates for all temperature treatments. Cheeses stored at $1^{\circ} \mathrm{C}$ showed greater crystal coverage than cheeses stored at $5^{\circ} \mathrm{C}$ (Figure 2). The solubility of calcium lactate in aqueous solution decreases as temperature decreases. Pearce et al. (1973) demonstrated that the calcium lactate in aqueous solution was less soluble at $0^{\circ} \mathrm{C}$ than at $4^{\circ} \mathrm{C}$. Cheeses stored at $10^{\circ} \mathrm{C}$ exhibited lower crystal coverage than those stored at $1^{\circ} \mathrm{C}$ and higher crystal coverage than those stored at $5^{\circ} \mathrm{C}$ for the first 20 wk of study (Figure 2). However, by the end of 30 wk, crystal coverage was higher for cheeses stored at $10^{\circ} \mathrm{C}$ than at the other 3 temperatures. This behavior was intriguing because calcium lactate is more soluble at higher temperatures. Therefore, less crystallization would be expected under $10^{\circ} \mathrm{C}$ storage than at $5^{\circ} \mathrm{C}$ or $1^{\circ} \mathrm{C}$, based simply on the relationship between temperature and solubility in aqueous solution. The steep

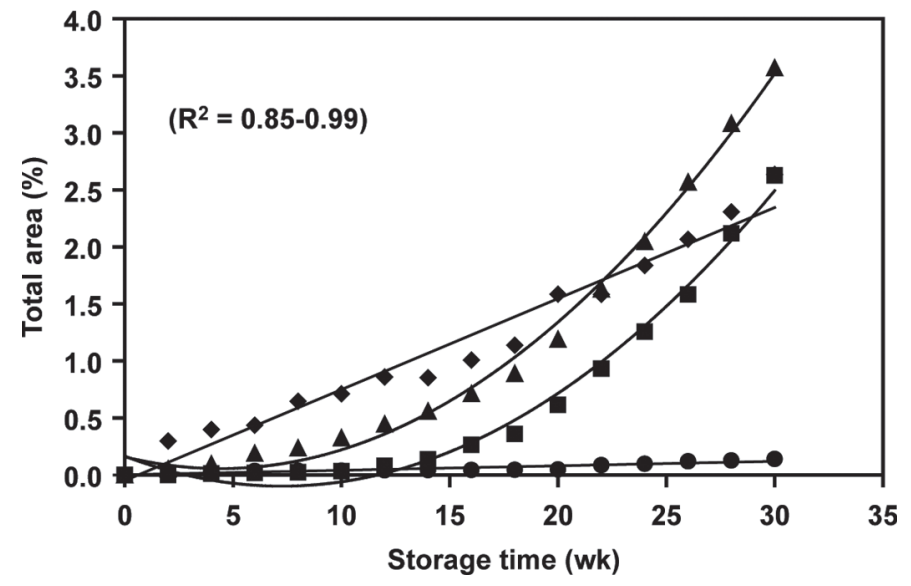

Figure 2. Changes in the total area occupied by calcium lactate crystals, expressed as a percentage of total cheese surface area, on surfaces of a retail sample of smoked Cheddar cheeses that were stored for 30 wk at $1^{\circ} \mathrm{C}(\bullet), 5^{\circ} \mathrm{C}(\bullet), 10^{\circ} \mathrm{C}(\boldsymbol{\Delta})$, and $1 / 10^{\circ} \mathrm{C}$ (cycling weekly between 1 and $\left.10^{\circ} \mathrm{C}, \boldsymbol{\square}\right)$.

increase in total area at $10^{\circ} \mathrm{C}$ indicated that confounding factors may play a role when cheeses are stored at elevated temperature.

Weekly temperature cycling between 1 and $10^{\circ} \mathrm{C}$ showed a similar pattern of total crystal coverage as that at $10^{\circ} \mathrm{C}$, and the total area was approximately $1 \%$ lower than that at $10^{\circ} \mathrm{C}$ (Figure 2). A steep increase in crystal coverage was apparent from wk 20 (Figure 2 ), which also suggests that temperature affected confounding factors that contributed to this behavior of crystal growth. The number of DCR (an indicator of crystal formation rate) for each of the 4 temperature treatments are compared in Figure 3. The number of DCR followed a nonlinear increase over the 30 -wk storage period. Storage time significantly affected the number of DCR, which increased over time. We found a significant interaction of temperature and storage time, which showed that the rates of increase were different among temperature treatments (Table 1). Cheeses stored at $5^{\circ} \mathrm{C}$ had fewer DCR than cheeses stored at $1^{\circ} \mathrm{C}$, which can be explained on the basis of solubility; that is, lower solubility at $1^{\circ} \mathrm{C}$ resulted in higher super-

Table 1. Degrees of freedom, mean squares (MS), and probabilities for total area measurements and number of discrete crystal regions (DCR) per unit of cheese surface area of smoked Cheddar cheese during 30 wk of storage at $4^{\circ} \mathrm{C}$

\begin{tabular}{|c|c|c|c|c|c|}
\hline \multirow[b]{2}{*}{ Factor } & \multirow[b]{2}{*}{ df } & \multicolumn{2}{|c|}{ Percent of total area } & \multicolumn{2}{|c|}{ DCR (no. $\left./ \mathrm{cm}^{2}\right)$} \\
\hline & & MS & $P$-value & MS & $P$-value \\
\hline Temperature $(\mathrm{T})$ & 3 & 7.477 & 0.103 & 52.656 & 0.24 \\
\hline Error 1 & 8 & 2.593 & & 30.344 & \\
\hline Storage time (S) & 15 & 4.149 & $<0.01$ & 1.890 & $<0.01$ \\
\hline $\mathrm{T} \times \mathrm{S}$ & 45 & 0.474 & $<0.01$ & 0.968 & 0.008 \\
\hline Error 2 & 120 & 0.087 & & 0.552 & \\
\hline
\end{tabular}




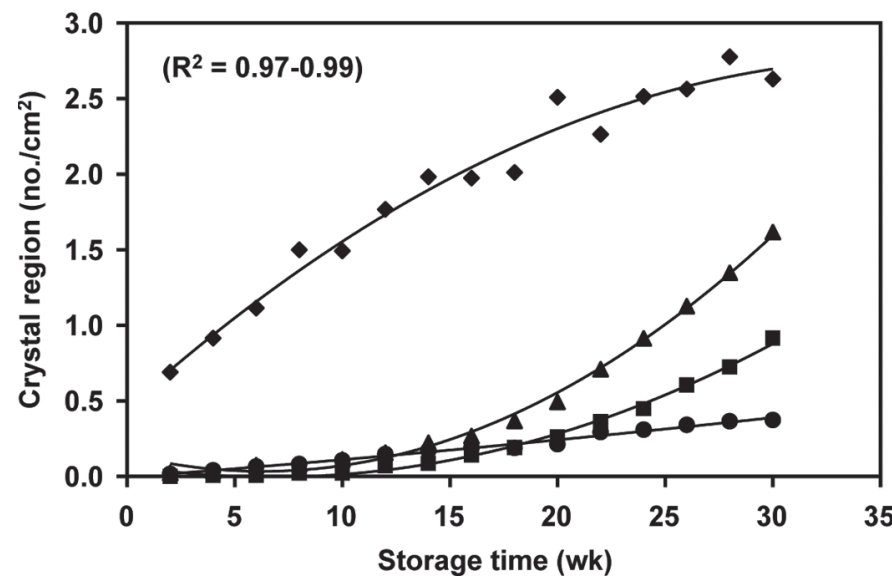

Figure 3. Number of discrete crystal regions expressed per unit of cheese surface area $\left(\mathrm{cm}^{2}\right)$, on surfaces of a retail sample of smoked Cheddar cheeses that were stored for 30 wk at $1^{\circ} \mathrm{C}(\bullet), 5^{\circ} \mathrm{C}(\bullet), 10^{\circ} \mathrm{C}$ $(\boldsymbol{\Delta})$, and $1 / 10^{\circ} \mathrm{C}$ (cycling between 1 and $\left.10^{\circ} \mathrm{C}, \mathbf{\square}\right)$.

saturation, which in turn enabled more nuclei to form at different sites at the cheese surface, ultimately giving rise to an increase in DCR number. More DCR were observed at $5^{\circ} \mathrm{C}$ compared that observed with $1 / 10^{\circ} \mathrm{C}$ and $10^{\circ} \mathrm{C}$ until about wk 15 , after which the number of $\mathrm{DCR}$ in the $10^{\circ} \mathrm{C}$ and $1 / 10^{\circ} \mathrm{C}$ cycling treatments increased steeply relative to that at $5^{\circ} \mathrm{C}$.

The number of DCR for the $1^{\circ} \mathrm{C}$ treatment was higher than that of the $10^{\circ} \mathrm{C}$ treatment (Figure 3 ). This result contrasted with the data obtained for total area, where the percentage of crystal coverage was greater for $10^{\circ} \mathrm{C}$ compared with $1^{\circ} \mathrm{C}$ (Figure 2). The smaller number of DCR in cheeses stored at $10^{\circ} \mathrm{C}$ could be explained by the 2 different morphologies that were observed on the cheese surfaces. The first type consisted of pinpoint crystals or merged clusters of pinpoint crystals and the second type was a region of white haze. The morphology of the white haze resembled an amorphous, translucent layer of irregular shape. It can be hypothesized that at $10^{\circ} \mathrm{C}$, calcium lactate may have existed in an amorphous state and a crystalline state. Amorphous solids do not possess a distinguishable crystal lattice and they are usually more soluble than the crystalline form (Pandit, 2006). For the $10^{\circ} \mathrm{C}$ treatment, the white haze appeared to dominate and caused a large difference between 1 and $10^{\circ} \mathrm{C}$. Also at $10^{\circ} \mathrm{C}$, the lawn of amorphous layer could have been a suitable nucleation site for the pinpoint crystals. The imaging software is capable of distinguishing discrete circular objects from irregular clustered objects. The image analysis method counted the aggregation of amorphous layer as a single object, so the cheeses at $10^{\circ} \mathrm{C}$ had lower DCR count than those at $1^{\circ} \mathrm{C}$.

Changes in the area of individual DCR for all temperature treatments showed that area increased signifi- cantly over the 30 -wk period $(P<0.01)$. The average area of individual DCR ranged from 0.88 to $1.05 \mathrm{~mm}^{2}$ at the end of the study (Figure 4). Changes in area may be considered as the indicators of crystal growth rate, and the slopes of the regression lines did not differ significantly among the 4 temperature treatments $(P$ $>0.05)$, suggesting that the crystals increased in area at the same rate for cheeses subjected to different temperatures. Thus, the evidence supports the view that DCR that are formed on the surfaces of cheeses grow at the same rate regardless of storage temperature. This behavior may not be similar for crystals of different morphology, as observed in cheeses at $10^{\circ} \mathrm{C}$, which also exhibited a white haze in a somewhat amorphous state. All discrete crystals that were selected from the cheeses surfaces were circular, with a shape factor value of 1 , under all temperature conditions. Our previous study also illustrated that all DCR conformed to a circular shape from a 2-dimensional aerial view (Rajbhandari and Kindstedt, 2008).

To summarize, storage temperature had little or no effect on crystal growth rate as measured by the increase in area over time of the round pinpoint crystals chosen for this study. However, temperature strongly influenced the number of discrete regions that formed on the cheese surface during storage. Crystal formation rate, as influenced by solubility changes, appeared to be the dominant factor responsible for the temperaturedependent difference in crystal coverage and thus the severity of the defect with respect to cheeses stored at $1^{\circ} \mathrm{C}$ versus $5^{\circ} \mathrm{C}$. However, in the $10^{\circ} \mathrm{C}$ and $1 / 10^{\circ} \mathrm{C}$ treatments, solubility differences were not the only factor that gave varying results at different temperatures. As

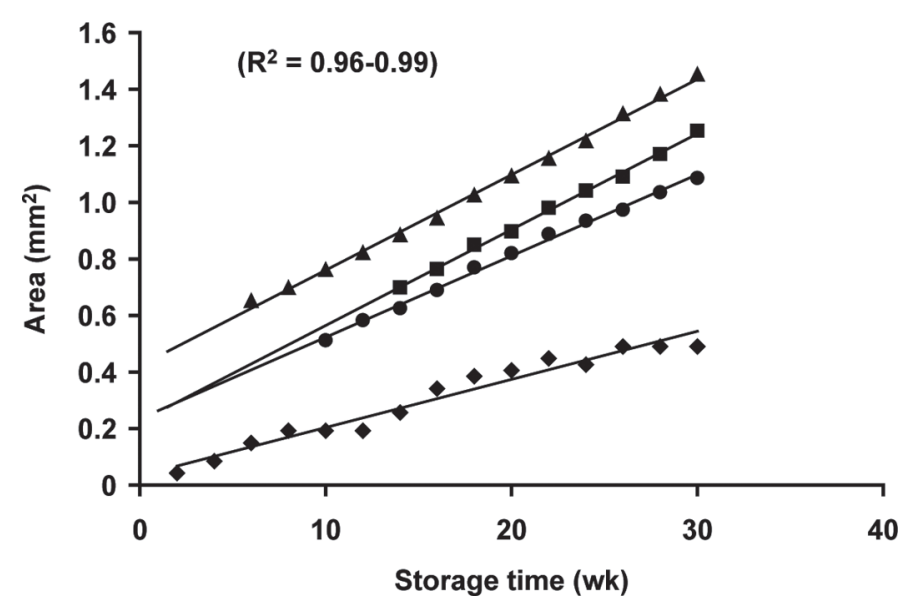

Figure 4. Changes in the area $\left(\mathrm{mm}^{2}\right)$ of discrete crystal regions on surfaces of a retail sample of smoked Cheddar cheese that was stored for 30 wk $1^{\circ} \mathrm{C}(\bullet), 5^{\circ} \mathrm{C}(\bullet), 10^{\circ} \mathrm{C}(\boldsymbol{\Delta})$, and $1 / 10^{\circ} \mathrm{C}$ (cycling weekly between 1 and $\left.10^{\circ} \mathrm{C}, \mathbf{\square}\right)$. 
Table 2. Average (mean of 2 replications) contents of $\mathrm{L}(+)$ and $\mathrm{D}(-)$ lactic acid and amounts of free moisture recovered from smoked surfaces of Cheddar cheese that were stored at 4 different temperature treatments for $45 \mathrm{wk}$

\begin{tabular}{|c|c|c|c|c|}
\hline \multirow{2}{*}{$\begin{array}{l}\text { Temperature } \\
\left({ }^{\circ} \mathrm{C}\right)\end{array}$} & \multicolumn{2}{|c|}{ Lactic acid (\%) } & \multirow{2}{*}{$\begin{array}{l}\text { Ratio } \\
\text { (D:L) }\end{array}$} & \multirow{2}{*}{$\begin{array}{c}\text { Free } \\
\text { moisture }(\mathrm{mg})\end{array}$} \\
\hline & $\mathrm{D}(-)$ & $\mathrm{L}(+)$ & & \\
\hline 1 & 0.532 & 0.802 & $0.66: 1$ & 10 \\
\hline 5 & 0.610 & 0.708 & $0.86: 1$ & 15 \\
\hline 10 & 0.682 & 0.693 & $0.98: 1$ & 60 \\
\hline $1 / 10^{1}$ & 0.447 & 0.741 & $0.60: 1$ & 45 \\
\hline
\end{tabular}

${ }^{1}$ Temperature cycling weekly between 1 and $10^{\circ} \mathrm{C}$.

we mentioned earlier, confounding factors played a role in crystal development for different temperatures.

Possible confounding factors may include (1) syneresis induced at higher temperature, and (2) racemization of $\mathrm{L}(+)$ to $\mathrm{D}(-)$ lactate. The lawn of translucent layer observed at $10^{\circ} \mathrm{C}$ could be due to the syneresis that occurred because of high temperature. It has long been known that high temperature causes syneresis of curds (Walstra and Jenness, 1984). This translucent layer, when observed over a period of time, appeared to give rise to 2 separate phenomena: (1) discrete crystal formation sites that developed into visible clusters or pinpoint crystals under the translucent layer (Figure 5); (2) a pool of solution on the surfaces of cheeses stored at $10^{\circ} \mathrm{C}$ that created an amorphous crystal lawn that manifested itself as a white haze, through which pinpoint crystals underneath remained visible. This observation was supported by measuring the free serum formed on the surfaces of all cheese samples at the end of the study. Table 2 shows that the average amount of free moisture appeared to increase as storage temperature increased, with amount of free moisture formed on cheeses being greatest at $10^{\circ} \mathrm{C}$ and least at $1^{\circ} \mathrm{C}$.

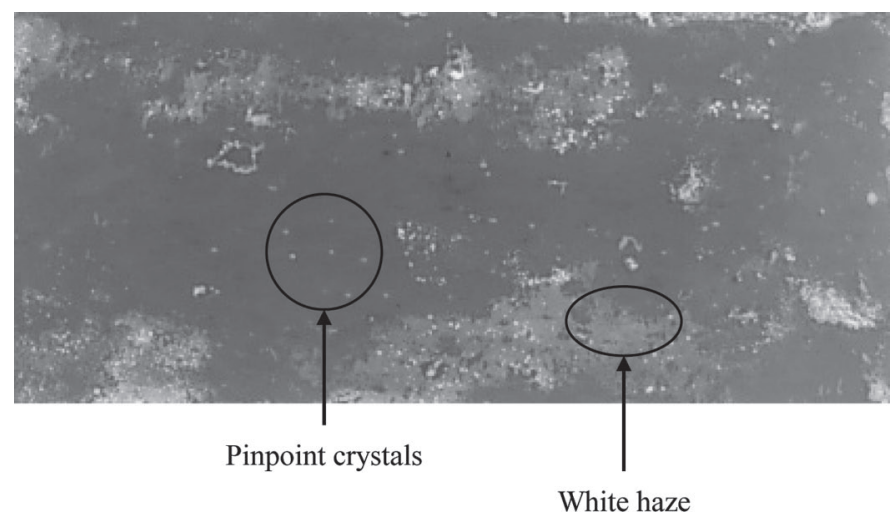

Figure 5. Digital image of one surface of a retail sample of smoked Cheddar cheese that was stored for 30 wk at $10^{\circ} \mathrm{C}$. Calcium lactate crystals appear as white discrete pinpoint regions and clusters against the gray cheese surface; also evident are opaque irregular regions of white haze.
When the temperature is increased, the growth rate of nonstarter bacteria also increases, which increases the rate of $\mathrm{D}(-)$ lactate formation from $\mathrm{L}(+)$ ) (Turner and Thomas, 1980). Consistent with this, Agarwal et al. (2006a) reported that Cheddar cheeses with added NSLAB stored at $10^{\circ} \mathrm{C}$ produced significantly higher concentrations of $\mathrm{D}(-)$ lactic acid than cheeses stored at $7.2^{\circ} \mathrm{C}$. Furthermore, it has been demonstrated that the racemic mixture of DL-lactic acid has lower solubility than the $\mathrm{L}(+)$ form (Cao et al., 2001). Thus, it is possible that NSLAB proliferated at the higher temperatures in the present study and converted $\mathrm{L}(+)$ lactic acid to the $\mathrm{D}(-)$ form, which in turn crystallized more readily because of the lower solubility. As observed in Figure 3, beyond wk 15, the DCR number increased at an accelerated rate for the $10^{\circ} \mathrm{C}$ and $1 / 10^{\circ} \mathrm{C}$ treatments relative to the $5^{\circ} \mathrm{C}$ treatment, opposite of what would be expected based on solubility. The conversion of $\mathrm{L}(+)$ to $\mathrm{D}(-)$ in wk 15 might have caused the increase in DCR number. To evaluate whether racemization of lactic acid from the $\mathrm{L}(+)$ to $\mathrm{D}(-)$ form was increased at higher storage temperature, we analyzed cheese samples for $\mathrm{D}(-)$ and $\mathrm{L}(+)$ lactic acid contents at the end of the study (30 wk). High levels of $\mathrm{D}(-)$ lactic acid in cheeses stored at $10^{\circ} \mathrm{C}$ compared with the other temperature treatments suggested that nonstarter bacteria were involved in lactate racemization at the higher storage temperature (Table 2). Cheese $\mathrm{pH}$ may also have been a confounding factor in the present study. Agarwal et al. (2006b) demonstrated that low postmanufacture $\mathrm{pH}$ of cheese led to enhanced occurrence of calcium lactate crystals as a result of greater concentrations of calcium and lactate ions in the cheese serum. Cheese $\mathrm{pH}$ was not measured at the beginning of this study, but it is unlikely that fermentation of residual lactose contributed to our test results because the cheeses were 8 to 10 mo of age at the start of the study and likely contained no unfermented lactose.

\section{CONCLUSIONS}

Crystal growth on the surfaces of Cheddar cheeses was strongly affected by temperature. The total area, 
which is believed to be a quantitative index of what the consumer sees on the cheese, was highest at $10^{\circ} \mathrm{C}$ due to syneresis and formation of the $\mathrm{D}(-)$ form of lactate, possibly caused by activity of NSLAB and $\mathrm{pH}$ changes, which resulted in formation of various forms of calcium lactate crystals (i.e., individual pinpoint crystals, merged clusters of pinpoint crystals, and amorphous white haze) on the surface. The number of DCR, an indirect measure of the crystal formation sites, showed that calcium lactate could occur in 2 different types of morphologies at elevated temperature. In terms of individual DCR area, it was evident that area increased at the same rate regardless of temperature. We conclude that the role of temperature is multifaceted and has a complex effect on total area, crystal formation rate, and morphology at different temperatures.

\section{ACKNOWLEDGMENTS}

The financial support of the New England Dairy Promotion Board (Winooski, VT), Vermont Dairy Promotion Council (Montpelier), and USDA Hatch Project VT-HO1305 are gratefully acknowledged.

\section{REFERENCES}

Agarwal, S., J. R. Powers, B. G. Swanson, S. Chen, and S. Clark 2006b. Cheese $\mathrm{pH}$, protein concentration, and formation of calcium lactate crystals. J. Dairy Sci. 89:4144-4155.

Agarwal, S., K. Sharma, B. G. Swanson, G. Ü. Yüksel, and S. Clark. 2006a. Nonstarter lactic acid bacteria biofilms and calcium lactate crystals in Cheddar cheese. J. Dairy Sci. 89:1452-1466.

Cao, X. H. J. Lee, H. S. Yun, and Y. M. Koo. 2001. Solubilities of calcium and zinc lactate in water and water-ethanol mixture. Korean J. Chem. Eng. 18:133-135.

Chou, Y.-E., C. G. Edwards, L. O. Luedecke, M. P. Bates, and S. Clark. 2003. Nonstarter lactic acid bacteria and aging temperature affect calcium lactate crystallization in Cheddar cheese. J. Dairy Sci. 86:2516-2524

Conochie, J., J. Czulak, A. J. Lawrence, and W. F. Cole. 1960. Tyrosine and calcium lactate crystals on rindless Cheddar cheese. Aust. J. Dairy Technol. 15:120.

Dybing, S. T., J. A. Wiegand, S. A. Brudvig, E. A. Huang, and R. C. Chandan. 1988. Effect of processing variables on the formation of calcium lactate crystals on Cheddar cheese. J. Dairy Sci. 71:1701-1710.

Farrer, K. T. H., and W. C. J. Hollberg. 1960. Calcium lactate on rindless cheese. Aust. J. Dairy Technol. 15:151-152.
Harper, W., A. Swanson, and H. Sommer. 1953. Observations of the chemical composition of white particles in several lots of Cheddar cheese. J. Dairy Sci. 36:368-372.

Hartel, R. W. 2001. Crystallization in Foods. Aspen Publishers, Gaithersburg, MD.

Johnson, M. E., B. A. Riesterer, C. Chen, B. Tricomi, and N. F. Olson. 1990a. Effect of packaging and storage conditions on calcium lactate crystallization on the surface of Cheddar cheese. J. Dairy Sci. 73:3033-3041.

Johnson, M. E., B. A. Riesterer, and N. F. Olson. 1990b. Influence of nonstarter bacteria on calcium lactate crystallization on the surface of Cheddar cheese. J. Dairy Sci. 73:1145-1149.

Kubantseva, N., R. W. Hartel, and P. A. Swearingen. 2004. Factors affecting solubility of calcium lactate in aqueous solutions. J. Dairy Sci. 87:863-867.

Marshall, R. T. 1993. Standard Methods for the Examination of Dairy Products. 16th ed. American Public Health Association, Washington, DC.

McDowall, F. H., and A. K. R. McDowell. 1939. The white particles in mature Cheddar cheese. J. Dairy Res. 10:118-119.

Pandit, N. K. 2006. Solubility and lipophilicity. Chapter 3 in Introduction to the Pharmaceutical Sciences. 1st ed. Lippincott Williams \& Wilkins, Baltimore, MD.

Pearce, K. N., L. K. Creamer, and J. Gilles. 1973. Calcium lactate deposits on rindless Cheddar cheese. N.Z. J. Dairy Sci. Tech. 8:3-7.

Rajbhandari, P., and P. S. Kindstedt. 2005a. Compositional factors associated with calcium lactate crystallization in smoked Cheddar cheese. J. Dairy Sci. 88:3737-3744.

Rajbhandari, P., and P. S. Kindstedt. 2005b. Development and application of image analysis to quantify calcium lactate crystals on the surface of smoked Cheddar cheese. J. Dairy Sci. 88:4157-4164.

Rajbhandari, P., and P. S. Kindstedt. 2008. Characterization of calcium lactate crystals on Cheddar cheese by image analysis. J. Dairy Sci. 91:2190-2195.

Rajbhandari, P., J. Patel, E. Valentine, and P. S. Kindstedt. 2009. Chemical changes that predispose smoked Cheddar cheese to calcium lactate crystallization. J. Dairy Sci. 92:3616-3622.

Shock, A. A., W. J. Harper, A. M. Swanson, and H. H. Sommer. 1948 What's in those "white specks" on Cheddar? Wisc. Agric. Exp. Sta. Bull. 474. University of Wisconsin, Madison.

Swearingen, P. A., D. E. Adams, and T. L. Lensmire. 2004. Factors affecting calcium lactate and liquid expulsion defects in Cheddar cheese. J. Dairy Sci. 87:574-582.

Tuckey, S. L., H. A. Ruehe, and G. L. Clark. 1938. X-ray diffraction analysis of white specks in Cheddar cheese. J. Dairy Sci. Abstr. $21: 161$

Turner, K. W., and T. D. Thomas. 1980. Lactose fermentation in Cheddar cheese and the effect of salt. N.Z. J. Dairy Sci. Tech. $15: 265-276$.

Walstra, P., and R. Jenness. 1984. Dairy Chemistry and Physics. John Wiley \& Sons Inc., New York, NY.

Washam, C. J., T. J. Kerr, V. J. Hurst, and W. E. Rigsby. 1985 A scanning electron microscopy study of crystalline structures on commercial cheese. Dev. Indust. Microbiol. 26:749-761. 